\title{
Experimental Study on Mechanical Property of X-Type-Slag Cement Concrete
}

\author{
Sun Ling ${ }^{1}$, Yu Wenyong ${ }^{1}$, He Dongbiao ${ }^{2}$, Lin Lin ${ }^{1}$ and Wang Jiamei $^{2}$ \\ ${ }^{1}$ Heilongjiang Institute of Technology, China \\ ${ }^{2}$ Highway Bureau of Heilongjiang Province, China
}

\begin{abstract}
Key words : X-type slag, cement concrete, specimens experiment, workability, strength
Abstract: X-type-slag is rich in $\mathrm{Fe} 2 \mathrm{O} 3$ so that it can absorb microwave and generate heat easily. By replacing some sand with X-type-slag, cement concrete can improve the function of removing ice with microwave. The feasibility has been verified through specimens experiments tested in lab. The results show: while X-type-slag dosage is less than $50 \%$ of sand, the workability and strength of cement concrete meet the requirements of specification. Therefore, X-type-slag can be used in cement concrete pavement so as to improve the deicing effect.
\end{abstract}

\section{Introduction}

In northern China, north America, northern Europe and Siberia and other high latitude regions, the snow falls heavily in four to six months of each year, which is common that the pavement is covered with snow and ice during long winter. The friction coefficient of the pavements is lesser than normal value, and vehicles are very difficult to drive and brake, resulting in frequent traffic accidents and heavy lives and properties lost. There are three kinds of existences of snow and ice on the pavement, fresh snow, snow dune and ice film and ice dune. In the situation, adhesion coefficient of the pavements decreases largely, which makes braking distance increase, and traffic accidents occur easily. Some references showed traffic accidents in winter in cold regions are 20 percent more than that in other seasons. According to the investigation results of the major cities in the world, traffic accidents caused by icing roads account for more than $35 \%$ of total traffic accidents in winter. The research of deicing snow on the roads in winter is under way in the countries at high latitude areas around the world(Ren,2014).

At present, the common methods of removing snow and ice on roads around the world are of chemical, thermal and mechanical methods. The chemical method to remove ice and snow is to spread chemical materials on pavements, such as salts $(\mathrm{NaCl}, \mathrm{CaCl} 2)$ and some other new type melting snow agent and deicing agent etc., which can reduce the melting point of ice and snow and protect them from freezing. Although this way works, the negative effect brought is very serious. Salts, especially chlorine salt, can erode the pavements seriously, make pavement crack, make surface layer peel off and make lifetime of road shorten. Another one is that the salt melted infiltrates into surface layer of soil or inflows into farmland, making serious pollution to rivers and farmland. In addition, melting snow agent is poor as the environment temperature is lower than $15^{\circ} \mathrm{C}$ and is useless as the environment temperature is lower than $-18^{\circ} \mathrm{C}$ (Wang,2005). The heating deicing method is to remove ice by heating the surface of pavement, which is divided into two ways, one is infrared heating and the other is electric heating. The heating way can remove ice film instead of ice block, but energy lost badly. The mechanical way is to cut off the ice and snow on the roads by equipments, such as snow remover with shovel and removing snow machine with brush roller and rotary snow lifting machine etc.. The snow can be removed efficiently, but ice is difficult to remove. As ice adheres to surface of roads tightly, it is hard for mechanical force to peel off the ice. Moreover, it is difficult to control the mechanical operation of crushing force to ice on the roads, and make the pavements and marking signs damage(LI,2003).

In view of the disadvantages of the above deicing methods, the application of microwave deicing has been developed abroad. Ice doesn't absorb microwave basically, as the road surface is irradiated by microwave, which penetrates through ice film. Pavement can absorb the heat transformed from microwave energy and its temperature is higher than other region of pavements. Ice covering the 
road will melt and ice film will be peeled off from the surface of roads(Jiao,2008). Microwave heating effect depends on materials characteristics of pavement. X-type-slag is rich in Fe2O3, replacing some sand with $\mathrm{X}$-type-slag. The cement concrete will absorb the heat made by microwave and be heated efficiently. As the byproduct of copper smelting industry, X-type-slag is difficult to be stacked and to be protected from polluting environment. In this essay, this industrial metallurgical slag can be added to the cement concrete. Through mechanical property analysis of specimens experiments tested in lab, microwave deicing effect will be studied.

\section{Raw materials for experiments}

Cement: selected from Tan E PO 42.5 Ordinary Portland Cement made by Harbin Cement Plant, the compressive strength and flexural-tensile strength for the third day are $27.6 \mathrm{MPa}, 4.8 \mathrm{MPa}$; and $48.9 \mathrm{MPa}, 7.8 \mathrm{MPa}$ for the 28th day. The basic chemical ingredients are showed in table1.

Table 1. the basic ingredients of $42.5 \mathrm{PO}$.

\begin{tabular}{|c|c|c|c|}
\hline Ingredients & $\mathrm{SiO}_{2}$ & $\mathrm{Fe}_{2} \mathrm{O}_{3}$ & $\mathrm{Al}_{2} \mathrm{O}_{3}$ \\
\hline $\begin{array}{c}\text { Contents } \\
(\%)\end{array}$ & 22.12 & 5.42 & 4.32 \\
\hline Ingredients & $\mathrm{CaO}$ & $\mathrm{MgO}$ & $\mathrm{K}_{2} \mathrm{O}$ \\
\hline $\begin{array}{c}\text { Contents } \\
(\%)\end{array}$ & 63.18 & 0.99 & - \\
\hline $\begin{array}{c}\text { Ingredients } \\
\text { Contents } \\
(\%)\end{array}$ & - & 2.20 & $\begin{array}{c}\text { Lost of } \\
\text { ignition }\end{array}$ \\
\hline
\end{tabular}

X-type slag: comes from a smelting plant in Anhui province. The basic ingredients are $\mathrm{Fe}_{2} \mathrm{O}_{3}$, $\mathrm{SiO}_{2}$, Mohs Scale of Mineral Hardness is 6-7, surface dry density is $3.60 \mathrm{~g} / \mathrm{cm}^{3}$, bulk density is $1.75 \mathrm{~g} / \mathrm{cm}^{3}$, void ratio is $51.9 \%$, its color is bright black and angular shape. The basic ingredients are showed in table2

Table 2. Basic Chemical Ingredients of X-type-slag.

\begin{tabular}{|c|c|c|c|}
\hline Ingredients & $\mathrm{Fe}_{2} \mathrm{O}_{3}$ & $\mathrm{SiO}_{2}$ & $\mathrm{FeO}$ \\
\hline Contents (\%) & 42.28 & 28.54 & 11.06 \\
\hline Ingredients & $\mathrm{Al}_{2} \mathrm{O}_{3}$ & $\mathrm{CaO}$ & $\mathrm{MgO}$ \\
\hline Contents (\%) & 2.44 & 11.98 & 2.81 \\
\hline Ingredients & $\mathrm{K}_{2} \mathrm{O}$ & $\mathrm{Na}_{2} \mathrm{O}$ & $\mathrm{CuO}$ \\
\hline Contents (\%) & - & - & 0.20 \\
\hline
\end{tabular}

Admixture: a FN-C-type high efficiency water reducing agent made by Harbin Xiangyang Longke Concrete Technology Development Co., Ltd., and its water reduction rate is not less than $15 \%$.

Sand: surface dry density is $2.65 \mathrm{~g} / \mathrm{cm}^{3}$, bulk density is $1.57 \mathrm{~g} / \mathrm{cm} 3$, fineness modulus is 2.3 , medium coarse sand, meets the requirements of "Technical specification for construction of Highway Cement Concrete Pavement” (JTG F30-2003).

Replacing some sand with X-type-slag, there are grading requirements to fine aggregates for pavement concrete, sieve analysis tests are made to the sand and X-type-slag, the results showed in table3.

Stones: $4.75 \mathrm{~mm} \sim 31.5 \mathrm{~mm}$ continuous grading crushed stones, the grains shape desired, meets the requirements of "Technical Specification for Construction of Highway Cement Concrete Pavement" (JTG F30-2003). The technical index tested is showed in table4. 
Table 3. Tests of Sieve Analysis.

\begin{tabular}{|c|c|c|c|}
\hline $\begin{array}{c}\text { Sieve } \\
\text { sizes/mm }\end{array}$ & $\begin{array}{c}\text { sand } \\
(\mathrm{Ai}) / \%\end{array}$ & $\begin{array}{c}\text { X-type-slag } \\
(\mathrm{Ai}) / \%\end{array}$ & $\begin{array}{c}\text { Gradation } \\
\text { ranges/\% }\end{array}$ \\
\hline 4.75 & 2.4 & 0 & $0 \sim 10$ \\
\hline 2.36 & 14.5 & 31.5 & $0 \sim 25$ \\
\hline 1.18 & 27.3 & 85.9 & $10 \sim 50$ \\
\hline 0.6 & 45.5 & 99.6 & $41 \sim 70$ \\
\hline 0.3 & 83.8 & 100 & $70 \sim 92$ \\
\hline 0.15 & 96.6 & 100 & $90 \sim 100$ \\
\hline
\end{tabular}

Table 4. Technical Index of Crushed Stones

\begin{tabular}{|c|c|c|c|}
\hline items & Crushing value/\% & $\begin{array}{c}\text { Needle and flake } \\
\text { content/\% }\end{array}$ & $\begin{array}{c}\text { Mud } \\
\text { content/\% }\end{array}$ \\
\hline The results & 7.8 & 8.6 & 0.8 \\
\hline items & $\begin{array}{c}\text { Apparent } \\
\text { density/g. } \mathbf{c m}^{-3}\end{array}$ & Bulk density $/ \mathbf{g} \cdot \mathbf{c m}^{-3}$ & $\begin{array}{c}\text { Void } \\
\text { ratios/\% }\end{array}$ \\
\hline The results & 2.72 & 1.48 & 45.5 \\
\hline
\end{tabular}

\section{Experimental method}

\subsection{Mix Ratio}

In this essay, the mechanical properties of specimens with the flexural-tensile design strength of 5.0Mpa with X-type slag are studied.

In order to study microwave deicing efficient to specimens with different ratio of X-type-slag to sand, such eight groups of specimens are designed and made. The ratios are: (1)100:0,(2)90:10,(3) 80:20,(4)70:30,(5)60:40,6)50:50, (7)40:60,8)30:70, and numbered with 1,2,3,4,5,6,7,8, showed in table5.

Table 5. Mix Ratio of the specimens with different ratio of X-type-slag to sand $/ \mathrm{kg} \cdot \mathrm{m}^{-3}$

\begin{tabular}{|c|c|c|c|c|c|}
\hline No. & cement & sand & X-slag & $\begin{array}{c}\text { Crushed } \\
\text { stone }\end{array}$ & $\begin{array}{c}\text { admixt } \\
\text { ure }\end{array}$ \\
\hline 1 & 379 & 625 & 0 & 1270 & 7.58 \\
\hline 2 & 379 & 562 & 63 & 1270 & 7.58 \\
\hline 3 & 379 & 500 & 125 & 1270 & 7.58 \\
\hline 4 & 379 & 438 & 187 & 1270 & 7.58 \\
\hline 5 & 379 & 375 & 250 & 1270 & 7.58 \\
\hline 6 & 379 & 312 & 313 & 1270 & 7.58 \\
\hline 7 & 379 & 250 & 375 & 1270 & 7.58 \\
\hline 8 & 379 & 188 & 437 & 1270 & 7.58 \\
\hline
\end{tabular}

\subsection{Testing for the workability of concrete with X-type-slag}

Forcing type mixing machine is used to produce concrete. According to the ratio of X-type-slag to sand, the two materials are mixed and the workability of the concrete is tested. The slump of 8 groups of concrete mixtures meets the requirements, but the viscosity and water retention are very different. When the ratio of X-type-slag to sand is equal, the fine aggregate gradation cannot meet the second district grading scope requirements, the water retention of the concrete mixture is poor, and some water is leaking out. As the ratio of X-type-slag to sand is increasing, phenomenon of bleeding will be obviously shown by Figure1. 




Figure1. Status of Different X-type-slag dosage

\subsection{Study on Mechanical Property of X-type-slag Concrete}

Eight groups of concrete specimens are made with the mixtures above. The size of beams is $150 \mathrm{~mm} \times 150 \mathrm{~mm} \times 550 \mathrm{~mm}$, keeping which cured in $7 \mathrm{~d}$ and $28 \mathrm{~d}$. The value of flexural-tensile strength of the different specimen is shown in table6.

Table 6. Values of Different Groups of Concrete Specimens.

\begin{tabular}{|c|c|c|c|}
\hline $\begin{array}{c}\text { No. of } \\
\text { Specimen }\end{array}$ & $\begin{array}{c}\text { X-type- } \\
\text { slag } \\
\text { Ratio }\end{array}$ & $\begin{array}{c}\text { 7d Flexural } \\
\text { Tensile } \\
\text { Strength/Mp } \\
\text { a }\end{array}$ & $\begin{array}{c}\text { 28d Flexural } \\
\text { Tensile } \\
\text { Strength/Mp } \\
\text { a }\end{array}$ \\
\hline 1 & $100: 0$ & 5.32 & 6.05 \\
\hline 2 & $90: 10$ & 5.37 & 6.18 \\
\hline 3 & $80: 20$ & 5.55 & 5.28 \\
\hline 4 & $70: 30$ & 5.51 & 6.33 \\
\hline 5 & $60: 40$ & 5.33 & 6.20 \\
\hline 6 & $50: 50$ & 5.15 & 5.92 \\
\hline 7 & $40: 60$ & 4.88 & 5.81 \\
\hline 8 & $30: 70$ & 4.81 & 5.67 \\
\hline
\end{tabular}

From table 6 above, the relationship of X-type-slag concrete and flexural-tensile strength is shown as follows. As the ratio of X-type-slag to sand is $1: 1,7 \mathrm{~d}$ and $28 \mathrm{~d}$ strengths are little more than the normal concrete. As the ratio of X-type-slag to sand is larger than $1: 1$, the fineness modulus is more than 3.5, the fine aggregates can't meet the second grading scope requirements, and the sand ratio of concrete mixture is the same. As the ratio of X-type-slag to sand increases, the flexural tensile strength of $7 \mathrm{~d}$ and $28 \mathrm{~d}$ will decrease. As the density of X-type-slag is more than the sand and with some property of volcano ash action, their correspondent flexural-tensile strength can meet the requirements of 5.7Mpa, and the fracture surface of specimens shows that the X-type-slag is distributed evenly.

The Figure 2 shows No.1 and No.6 specimens.

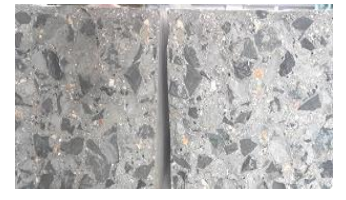

Section of No.1Specimen

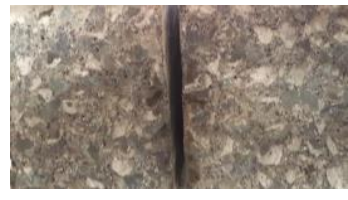

Section of No.6Specimen

Figure2. Fracture Surface of X-slag Concrete

The conclusion is that replacing some sand with X-type-slag in cement concrete is feasible.

\section{Conclusions}

(1) X-type-slag is a material with high strength, hardness and wearing resistance, replacing some fine aggregates with the X-type-slag in cement concrete. As the ratio of X-type-slag to sand is 
less than 1:1, the gradation scope and fineness modulus can meet the requirements of pavement concrete.

(2) While the ratio of X-type-slag to sand is less than 1:1, the liquidity, viscosity and water retention of concrete can meet the requirements.

(3) The 28d flexural-tensile strength of the X-type-slag concrete meets the requirement of pavement concrete. X-type-slag can replace some sand in pavement cement concrete, and its strong magnetic effect on microwave absorption and heating can improve microwave deicing efficiency, only the ratio of $\mathrm{X}$-type-slag to sand is no more than $1: 1$.

\section{Acknowledgements}

Fund Project: Science and Technology Project of Heilongjiang Provincial Department of Transportation(2012-42); The Open Project of Freezing Region Road Engineering Technology Laboratory(HQKF-12-07)

\section{References}

[1] Ren Yi, Yuan Tongsen, Wan Zhi, Qin Min Current Deicing Technology Summary on Highway Abroad and China. [J]. Hunan Communication Science And Technology. 2014, 42(2)71-75

[2] Wang Lixun Study For Application of Deicing Liquid in Cold Area of China. [D]. Harbin Institute of Technology.2005.

[3] LI Xiao, Xu Yugong, Liu Fuli Application of microwave heating for ice removal on streets [J]. Journal of Harbin Institute of Technology2003, 35(11)1342-1343

[4] Jiao Shengjie, Tang Xiangwei, Gao Ziyu, Wang Qiang Influence of Environmental Temperature on Road Deicing Efficiency Using Microwave [J]. Journal of Chang'an University( Natural Science Edition). 2008(6)85-88 